\title{
Identification of Olympiad Material in Elementary Schools
}

\author{
Dea Stivani Suherman \\ Department of Primary School Teacher Education \\ Universitas Negeri Padang, Indonesia \\ deastivani@fip.unp.ac.id
}

\author{
Fanny Rahmatina Rahim \\ Department of Physics Education \\ Universitas Negeri Padang, Indonesia \\ fannyrahmatina@fmipa.unp.ac.id
}

\author{
Syamsu Arlis \\ Department of Primary School Teacher Education \\ Universitas Negeri Padang, Indonesia \\ syamsuarlis@ fip.unp.ac.id
}

\begin{abstract}
The elementary science Olympiad is the first step for talented students who are expected to continue following the Olympics at the next level. Based on the results of a preliminary analysis of the initial analysis conducted at SDN 30 Cengkeh, information was obtained that aspects of knowledge, creativity, student motivation, and depth of Science Olympiad material had not been reached optimally. One contributing factor is the unavailability of science Olympiad teaching materials that can facilitate students to improve these aspects. That is what underlies the development of teaching materials for elementary school science Olympiad. Data collected through observation, documentation, questionnaires, and interviews. This type of research is development research using the Plomp model which consists of preliminary research phases in the form of needs analysis, student analysis, and concept analysis. The purpose of this study is to obtain an analysis of the needs of Olympic teaching materials at the preliminary research stage which will be developed at the stage of next.
\end{abstract}

Keywords: preliminary research, science Olympiad, teaching materials

\section{INTRODUCTION}

The rapid development of science and technology to date has brought mankind to the era of global competition in various fields of life. Such a situation requires us to immediately improve ourselves and at the same time formulate concrete steps to meet the future [1]. The main step that must be considered and realized in the context of organizing education in elementary schools is how to prepare human resources who are strong in character, strong, withstood and have reliable abilities in their fields [2].

The elementary science Olympiad that was pioneered since 2003 is one of the strategic platforms for realizing the educational paradigm above. The ongoing implementation of the Olympics will have a positive impact on the implementation of the learning process so that it becomes more creative and innovative.

The paradigm that science is a difficult and unattractive is still actual today. Students are already familiar with simple and easy problems so that it influences students' interest in participating in the Science Olympiad and causes students to be unable to find complex science problem solutions, especially Olympic questions [3]. Olympic material is basically sourced from the curriculum that applies to textbooks, supporting books and other relevant material.

The material tested is a matter of exploration, reasoning, creativity, and understanding of concepts through the use of visual aids. Based on preliminary investigations that have been carried out at SDN 30 Cengkeh, the unavailability of teaching materials is in accordance with the Science Olympiad standards. Overcoming the problems raised, it is necessary to develop teaching materials for elementary school science
Olympics that are able to guide students in carrying out Olympic activities.

This Science Olympiad book uses the right techniques to make it easier for students to attend science Olympiad training. The teaching material was developed with the Plomp model bypassing the preliminary research stage with the aim of knowing the analysis of the need for Science Olympiad teaching materials to be developed. Analysis of needs on teaching materials to be developed includes the initial analysis, student analysis, and material analysis [4].

\section{METHOD}

This type of research is research-based development (educational design research). EDR is designing and developing interventions as solutions to complex educational problems, also to increase knowledge about the characteristics of interventions with the aim of developing and validating theories [4]. The development model was adapted from the Plomp model. The Plomp model consists of three stages, namely: (1) preliminary research, (2) prototyping phase, and (3) assessment phase [5]. The development procedure of the Mc. Kenney can be seen in Figure 1.

The preliminary research phase is carried out a needs analysis and context analysis based on literature review and observation so that the initial textbook design data is obtained [6]. The instrument for the preliminary research stage uses a questionnaire for the front-end analysis and student analysis, analysis sheet for material analysis. Data validity and practicality analysis techniques use a Likert scale with steps: (a) give a score for each item of answers: strongly agree (4), agree (3), disagree (2), and strongly disagree (1); (b) add up the score total of 
each validator for all indicators; and (c) assigning validity and practicality values by using the formula:

$$
P=\frac{f}{N} 100 \%
$$

Note: $\mathrm{P}$ is the final score, $\mathrm{f}$ is the score obtained, and $\mathrm{N}$ is the maximum score.

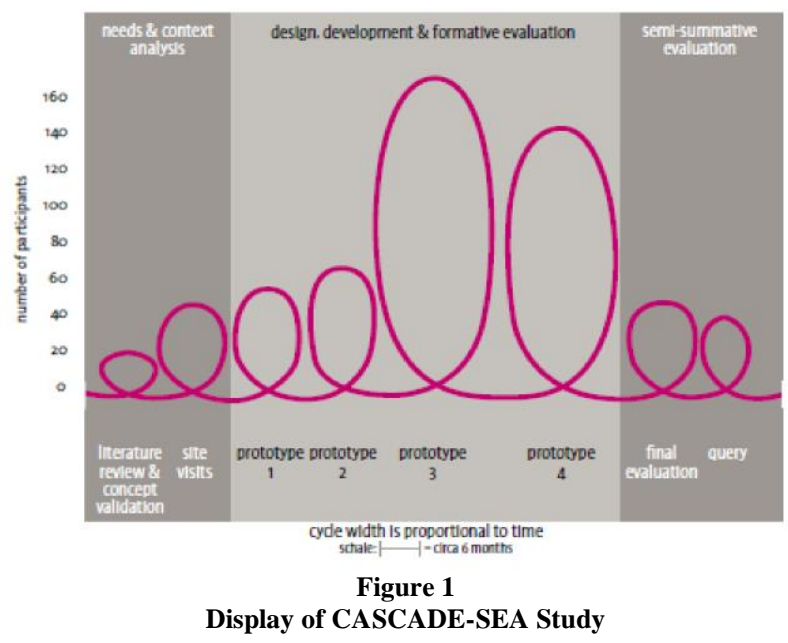

\section{RESULT}

\section{A. Beginning and End Analysis}

The initial and final analysis consists of performance analysis, graduate competency standard (SKL) analysis, job analysis, and analysis of learning difficulties. The results of the initial and final analysis can be seen in Table 2.

Table 1

Preliminary and Final Analysis Results

\begin{tabular}{|c|c|c|}
\hline No & Indicator & Category \\
\hline \multicolumn{3}{|c|}{ 1) Performa analysis } \\
\hline & a) Teacher & Good \\
\hline & b) Infrastructure & Good \\
\hline & c) Policy & Very good \\
\hline & d) Social climate & Very good \\
\hline \multicolumn{3}{|c|}{ 2) Analysis of graduate competency standard } \\
\hline & e) Spiritual value & Very good \\
\hline & f) Social value & Good \\
\hline & g) Knowledge & Moderate \\
\hline & h) Skill & Good \\
\hline \multicolumn{3}{|c|}{ 3) Job analysis } \\
\hline & i) Responsibility & Good \\
\hline & j) Leadership & Good \\
\hline & k) Discipline & Good \\
\hline & 1) Creative & Moderate \\
\hline & m) Good deeds & Good \\
\hline \multicolumn{3}{|c|}{ 4) Analysis of learning difficulty } \\
\hline & n) Motivation & Moderate \\
\hline & o) Supportive media & Good \\
\hline & p) Method & Good \\
\hline & q) Learning sources & Good \\
\hline & r) Material & Moderate \\
\hline
\end{tabular}

Based on the results of the analysis in Table 2, to minimize the problems of science Olympiad material, science olympiad teaching materials are needed. The design of teaching materials can make it easier for teachers to overcome students who have difficulty in solving complex science Olympics problems. Teaching materials are designed so that students are motivated to solve science Olympics problems so that students' characters grow such as curiosity, conscientiousness, cooperation, creative, critical and have good achievements in their fields.

\section{B. Student Analysis \\ 1. Competency Attitude Analysis}

The results of the analysis of students' studies on attitude competency can be seen in Figure 2. Figure 2 shows that the spiritual attitude of students is higher than the social attitude. From the results of the questionnaire given to students, students often pray before and after the completion of learning, then according to students' natural events associated with learning make their faith increase. Furthermore, for social attitudes, in the learning process, students often accept ideas or opinions of peers, while for proposing ideas to groups to be discussed in learning students rarely do.

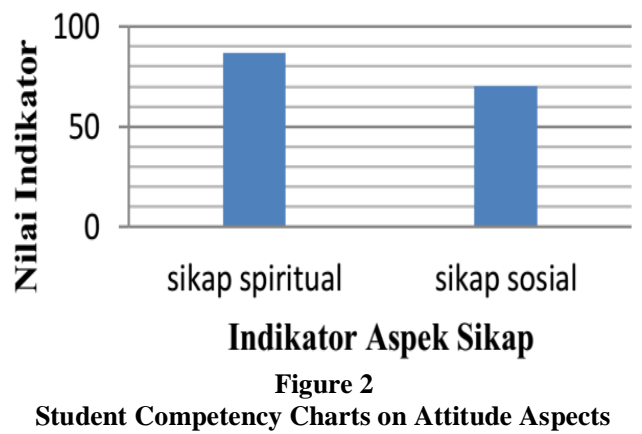

\section{Analysis of Knowledge Competency}

The results of students' analysis of research on knowledge competence can be seen in Figure 3. Figure 3 shows that the aspects of students' knowledge in conceptual and principal are lower than other aspects of knowledge. This is because the Olympiad material is difficult for students to understand, according to students it will be easier to understand if science learning is explained concepts and their application in daily life.

In addition, students' responses to the concept of science must be taught in simple language, given a lot of practice questions and the existence of learning resources that are easier to understand. Furthermore, students assume enthusiasm in learning science Olympiad because science is related to natural events, they consider it easier to understand the concepts and similarities.

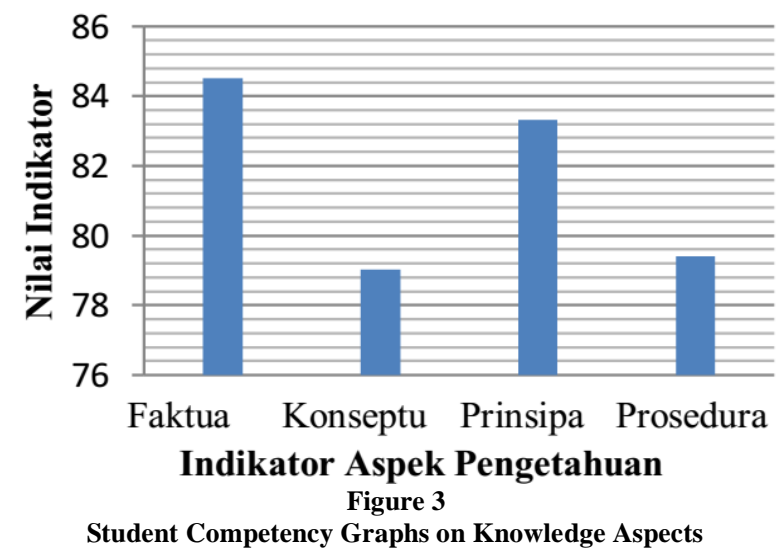




\section{Analysis of Competency Skills}

In addition to the analysis of knowledge and attitudes carried out also an analysis of skills. The results of students' analysis of research on knowledge competence can be seen in Figure 4.

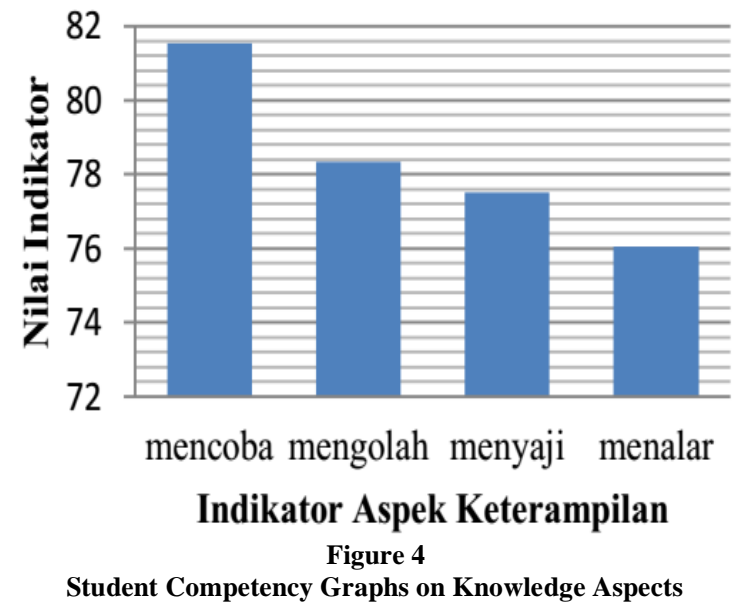

Figure 4 shows that aspects of student's skills in the reasoning aspects are lower than other aspects of skills. This is because there are still students who have difficulty in drawing conclusions from the experiments he did. However, most of the responses of students, with practicum/experiment can make it easier for students to understand the concepts and principles of science.

\section{Material Analysis}

Learning material is divided into facts, concepts, principles, and procedures. Analysis of the material carried out produces a variety of competencies needed by students. Competencies obtained from the material analysis are useful for formulating learning objectives. The formulation of learning objectives is useful for summarizing the results of the analysis of the material to determine the behavior of the research object, namely competency attitudes, knowledge, and skills.

Based on the theoretical studies that have been presented, it can be seen a discussion of the results of research with theoretical studies. This discussion will explain the results achieved in the study and the limitations encountered and several alternative solutions. The results of the study include a description of preliminary research (preliminary analysis), prototyping phase (design phase, development stage and formative evaluation), an assessment phase (assessment phase).

The results of Preliminary Research or the needs and context analysis stage show that the motivation of students to read teaching material is low. Learners have difficulty in completing the problem level analysis that requires the ability to reason. This happens because the needs of students have not been met. The teacher has not designed learning resources that are appropriate for the analysis of students' needs.

Important activities carried out in the preliminary analysis stage are the needs analysis (initial and final analysis, student analysis, and material analysis. The needs analysis instrument and context analysis are obtained from several literature reviews. Needs analysis is an ongoing process, data collection, to determine needs in achieving its objectives, this shows the importance of analyzing needs before developing learning resources in order to achieve learning goals [5].

The initial analysis was observed using an observation sheet. Things that were investigated in the initial analysis include performance analysis, SKL analysis, learning difficulty analysis, and job analysis [6]. The results of the initial analysis have formulated that the competencies developed are the competencies of students in translating and solving problems with the difficulty level of $\mathrm{C} 4$ and the creative spirit of students in creating a project. Analysis of students found that students are more enthusiastic in learning science related to natural events so that students are easy to understand the concepts and principles.

Learning difficulties of students can be seen based on subfactors, internal factors are divided into four, namely: interests, attention, motivation and study habits. Whereas external factors are divided into three, namely: teaching methods, learning media and learning resources (textbooks) [8]. As for the motivation of students in learning science if the concepts and principles of science are taught in simple language and associated with everyday life. In addition, students also need instructional media that can support overcoming difficulties in learning science that is solving complex problems [9].

The instructional media can also help teachers overcome students' learning difficulties [10], [11]. Based on the results of the analysis, instructional media is designed that is in accordance with the characteristics of students, material, and learning objectives so that the desired competencies are achieved. One of the instructional media is teaching material [12], [13].

The next analysis is material analysis, the material is grouped according to facts, concepts, principles, and procedures. The material is developed according to its aspects of both attitudes, knowledge and skills aspects. The teacher, in fact, has not analyzed the teaching material in developing learning resources. The material will be taught by students in the form of facts, concepts, principles, and procedures. Overall learning success depends on the success of the teacher in designing learning materials. Designing learning material has been done through material analysis [9].

\section{CONCLUSION}

The results of the initial investigation of teaching materials are carried out through several analyzes, namely the initial-end analysis, material analysis, student analysis, and regional potential analysis. The results of the initial analysis are to obtain sufficient identification of teacher performance, aspects of knowledge and skills must be improved, creative attitudes and responsibilities must be strengthened, and learning resources and materials must be maximized. The results of the student analysis phase are the deepening and strengthening of students' social attitudes, procedural and conceptual knowledge, and reasoning and serving skills. The results of the material analysis stage there are several materials that can be elaborated based on facts, concepts, principles, and procedures. 


\section{REFERENCES}

[1] Wiworo. "Olimpiade Matematika Dan IPA Sekolah Dasar/Madrasah Ibtidaiyah" Yogyakarta. Departemen Pendidikan Nasional. 2004.

[2] I. P. S. Putu, I. G. Nyoman, and I. H. Yudi, "Peningkatan kompetensi siswa berbakat dalam bidang olimpiade matematika tingkat SD," J. Widya Laksana, vol. 6, no. 2, pp. 100-112, 2017.

[3] F. Muliani and D. Noviati, "Pembinaan Peningkatan Mutu Pendidikan Bidang Olimpiade Sains Bagi Guru Sd Kota Langsa Provinsi Aceh," J. Pengabdi. Kpd. Masy., vol. 3 , no. 2,2018

[4] T. Plomp, "Educational design research: An introduction," Educ. Des. Res., pp. 11-50, 2013.

[5] H. Raval, S. Mckenney, and J. Pieters, "Remedial teaching in Indian under-resourced communities: Professional development of para-teachers," Int. J. Educ. Dev., vol. 38 , pp. 87-93, 2014.

[6] S. McKenney and T. C. Reeves, Conducting educational design research. Routledge, 2018.

[7] Y. Abidin, Desain sistem pembelajaran dalam konteks kurikulum 2013. Refika Aditama, 2014.
[8] A. Amerudin, E. Ariyati, and A. Nurdini, "Deskripsi Kesulitan Belajar dan Faktor Penyebabnya pada Materi Fungi di SMA Islam Bawari Pontianak dan Upaya Perbaikannya," J. Pendidik. Dan Pembelajaran Untan, vol. 2, no. 9, 2013

[9] S. Handayani, "Bahan Ajar Perencanaan Pembelajaran," Tersedia Httpfile Upi EduDirektoriFPTKJUR PEND Tek., 2012.

[10] P.-H. N. Wu and M. W. Marek, "Helping second language literature learners overcome e-learning difficulties: LETNET team teaching with online peer interaction," J. Educ. Learn., vol. 2, no. 4, pp. 87-101, 2013.

[11] M. C. Linn, H.-Y. Chang, J. Chiu, H. Zhang, and K. McElhaney, "Can desirable difficulties overcome deceptive clarity in scientific visualizations," Success. Rememb. Success. Forgetting Festschr. Honor Robert Bjork, pp. 239262,2010

[12] D. L. Rodgers and B. J. Withrow-Thorton, "The effect of instructional media on learner motivation," Int. J. Instr. Media, vol. 32, no. 4, p. 333, 2005.

[13] C.-W. Chang, J.-H. Lee, P.-Y. Chao, C.-Y. Wang, and G.D. Chen, "Exploring the possibility of using humanoid robots as instructional tools for teaching a second language in primary school," J. Educ. Technol. Soc., vol. 13, no. 2, pp. 13-24, 2010. 